\title{
53. An in-depth analysis of the professionalization process of the translation profession in Turkey from the perspective of the sociology of professions
}

\section{Nazan Müge UYSAL ${ }^{1}$}

\begin{abstract}
APA: Uysal, N. M. (2021). An in-depth analysis of the status quo of translation profession in Turkey from the perspective of trait theory of professionalization. RumeliDE Dil ve Edebiyat Araştırmaları Dergisi, (23), 841-860. DOI: 10.29000/rumelide.949710.
\end{abstract}

\begin{abstract}
Professionalization of translation has emerged as a recent field of research in the sociological approach in the relevant literature in translation studies. Professionalization can simply be described as a process covering several occupational attributes at the end of which an occupation upgrades its status. Studies investigating the translation profession and the status of translators in different countries are not high in number in translation studies literature. The present study aims at analyzing the current status of the translation profession in Turkey, drawing on the the professionalization process in the sociology of professions which aims to describe certain factors (traits, criteria) for an occupation to be accepted as a profession in this process. Translation is currently not a full-fledged profession in Turkey, like in most other countries around the world. However, the existence of translator education programs in universities, various translator associations and other developments related to legal procedures, particularly recent attempts of the Vocational Qualifications Institution suggest that the profession of translation in Turkey is a promising example on the way to professionalization. Especially recent developments linked to the release of a National Professional Standard for Translators/Interpreters established in 2013 and national qualifications in six different fields of translation (draft versions released in 2019) indicate the establishment of a well-founded translator certification system in Turkey soon.
\end{abstract}

Keywords: Translation profession, translator/interpreter, professionalization, the sociology of professions, translation market

\section{Meslek sosyolojisi çerçevesinde Türkiye'de çevirmenliğin meslekleşme süreci üzerine kapsamlı bir inceleme}

\section{$\ddot{O} \mathbf{z}$}

Çeviride meslekleşme çeviribilim literatüründe sosyolojik yaklaşımlar çerçevesinde yakın zamanda irdelenmeye başlanan bir araştırma alanıdır. Meslekleşme bir işin veya çalışma alanının, meslek olma yolunda gerekli olan belirli kriterleri tamamlayarak, mesleksel statüsünün yükseldiği bir süreç olarak tanımlanabilir. Çeviribilim literatüründe çevirmenlik mesleği ve çevirmenlerin farklı ülkelerdeki durumunu inceleyen çalışmaların sayısı fazla değildir. Bu çalışmanın amacı çevirmenliğin Türkiye'deki meslekleşme sürecini meslek sosyolojisi çerçevesinde analiz etmektir. Çevirmenlik, Türkiye'de, dünyanın pek çok ülkesinde olduğu gibi, henüz meslekleşme ölçütlerini tamamlamış bir meslek konumunda değildir. Öte yandan, akademik çeviri eğitimi programları ve farklı çeviri alanlarında faaliyet gösteren çevirmen örgütlerinin varlı̆̆ı ve resmi düzenlemelere yönelik Mesleki Yeterlilik Kurumunun liderliğinde son ylllarda yapılan çalışmalar Türkiye

Dr. Öğr. Üyesi, Bolu Abant İzzet Baysal Universitesi, Yabancı Diller Yüksek Okulu, Mütercim Tercümanlık Bölümü (Bolu, Türkiye), mugenazan@hotmail.com, ORCID ID: oooo-0oo1-8983-4367 [Araştırma makalesi, Makale kayıt tarihi: 02.04.2021-kabul tarihi: 20.06.2021; DOI: 10.29000/rumelide.949710]

\section{Adres Address}

RumeliDE Dil ve Edebiyat Araşttrmaları Dergisi $\quad$ RumeliDE Journal of Language and Literature Studies Osmanağa Mahallesi, Mürver Çiçeği Sokak, No:14/8 Osmanağa Mahallesi, Mürver Çiçeği Sokak, No:14/8

Kadıköy - İSTANBUL / TÜRKIYE 34714 Kadıköy - ISTANBUL / TURKEY 34714 e-posta: editor@rumelide.com

e-mail: editor@rumelide.com

tel: +90 505 7958124, +902167730616 phone: +90 505 7958124, +90 2167730616 
çevirmenliğin meslekleşme yolunda umut vaat eden bir profil çizdiğini göstermektedir. Özellikle 2013 yılında yayınlanmış olan Çevirmen Ulusal Meslek Standardı ve farklı çeviri alt-alanları için hazırlanmış ve 2019 yllında taslak olarak yayınlanmış olan mesleki yeterlilik belgeleri Türkiye'de yakın zamanda iyi yapılandırılmış bir çevirmen sertifikasyon sisteminin kurulacağını işaret etmektedir.

Anahtar kelimeler: Çevirmenlik mesleği, çevirmen, meslekleşme, meslek sosyolojisi, çeviri sektörü

\section{Introduction}

The 1990 s was the decade when, the translator, as the agent of a translation, captured the attention of scholars and emerged as a flesh-and-blood figure that deserved to be a topic of interest. This occurred because of the impact of the cultural and social turn in Translation Studies (henceforth, TS) which helped all concerned parties to comprehend what was going on in the world of translation both from the perspective of the translator and within the scope of professionalization. As a consequence, anything and everything connected with the translator agent such as the habitus of translators, translator organizations, translator certification systems, the problems faced by translators in different contexts such as rates of pay, working conditions, copyright ethics of translation, how the translation profession has developed and how it is perceived in public eye have emerged as recent research topics in TS.

Within this sociological paradigm in TS (Ar1, 2014; Chesterman, 2009; Gouanvic, 2005; Inghilleri, 2005; Paloposki, 2016; Wolf \& Fukari, 2007), there is a plethora of studies focusing on the status and professional identity of translators (Dam\& Zethsen, 2008, 2009, 2010, 2011, 2016; Godbout, 2016; Katan, 2009; Sela-Sheffy, 2016; Shavn, Ruokonen \& Salmi, 2018; Ruokonen, 2013, 2016; Venuti, 1986); professionalization in translation and the status of the translation profession in different countries (Dam\& Koskinen, 2016; Godbout, 2012; Gouadec, 2007; Kafi, Khoshsaligheh\& Hashemi, 2018; Kang\& Shunmugam, 2014; Katan, 2011; Seguinot, 2007; Stejkal, 2005; Uysal, 2015, 2017a, 2017b; Pym, Grin, Sfreddo \& Chan, 2012; Yllmaz-Gümüş, 2018); state of the translation industry (Abraham-Barna\& Abraham-Barna, 2016; Massardo\& Van de Meer, 2017; Romaine \& Richardson, 2009; Nimdzi, 2018; Pym et.al. 2012; Pym, Orrego-Carmona\& Torres-Simón, 2016), discussions on the roles of potential signals of translator competencies (certification, academic degrees, membership of translator organizations) on the translation industry (Chan, 2008, 2013) and translator certification procedures (Budin et. al., 2013; Chan, 2008; Hlavac, 2013; Stejkal, 2004, 2005; Uysal, 2017a, 2017b; Vigier\& Way, 2009). The results obtained in these studies demonstrate that translation is a semi or an emerging profession that is making substantial strides on the way to professionalization in many countries.

While the number of studies analyzing the status of translators and translation profession in different contexts has been increasing in number, the present study aims to contribute to this accumulated knowledge by investigating the professionalization process of translation in Turkey from the perspective of the sociology of professions. Thus, the article first provides an analysis of the concept of professionalization in translation and the sociology of professions (Section 2). In Section 3, the professionalization process of translation in Turkey is analyzed drawing on the the traits of the professionalization process. Section 3 basically covers the training requirements for the profession; professional translator associations; an overview of the current legislations concerning translators and

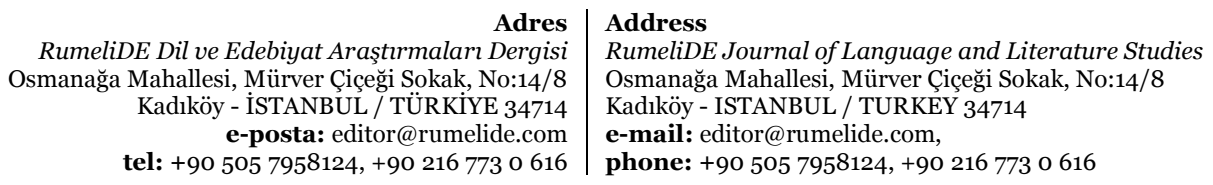


regulations in translation market in Turkey; and recent developments regarding the establishment of legal instruments for translation profession and translator certification procedures being carried out by a state-appointed authority, the Vocational Qualifications Authority (VQI, henceforth) responsible for organizing a National Vocational Qualifications System (NVQS). Finally, Section 4 presents a general discussion on the degree of professionalization of translation in Turkey.

\section{Translation profession from the perspective of professionalization in the sociology of professions}

Sociology situates professions within the system of occupations. Professions are occupations that consist of a maximum degree of five attributes, namely, systematic theory, authority, community sanction, ethical codes and a culture (Greenwood, 1980, p. 903), and according to Greenwood (1957, p. 45) the relationship between occupations and professions can be understood by means of a scale starting with unskilled occupations at one end and ending with professions on the other with increasing complexity (as cited in Godbout, 2012, p. 2). Sela-Sheffy (2016, pp. 132, 136) claims that "the sociology of professions tends to focus on highly-regarded, fully institutionalized occupations" which are at the top of this professional prestige scale. On the other hand, the status problems related to (anti-) professionalization which are central in the context of the lower-status or under-studied semi-professional occupations are often neglected in the sociological study of professions. She further makes a differentiation between institutionalized and prestigious liberal professions, also referred to as success stories and failed professionalizing occupations that are trying to empower their threatened status. To illustrate, while medicine, law and accounting fall in the first category, a number of occupational groups that are yet to be professionalized such as journalists, schoolteachers, craft artists and translators belong in the second group. Apparently, translation is accepted as an occupation rather than a profession, not appearing at the top of the professional prestige ladder (Katan, 2011, pp. 65, 84). Rather, it is a "quasi-profession" struggling to attain full professional status (Kang\& Shunmugam, 2014, p. 191; Dam\& Koskinen, 2016, p. 2; Dam\& Zethsen, 2016, p. 175)².

As Paloposki (2016) points out, the sociology of professions, which is mainly interested in theorizing professions, has dealt with professionalization from different perspectives, including the functionalist/trait theory, the power approach and the historical approach. Of all these, the most prevalent theory has been the trait theory and when professionalization is studied by disciplines other than sociology itself, generally a comparative or historical viewpoint has been used with a focus on the trait theory. The trait theory, emerging in the 1950s, aims to identify specific factors (traits, criteria) for an occupation to be accepted as a profession (Dam\& Zethsen ,2011, p. 978).

According to the trait theory, in order for an occupation to achieve the status of profession, a number of criteria should be met and this process is defined as professionalization. Millerson (1964) enlists the traits required on the way to professionalization as "the use of skills based on theoretical knowledge, education and training in these skills, the competence of professionals measured by examinations, a code of conduct to ensure professional integrity, performance of a service that is for the public good and a professional association that organizes members" (as cited in Yılmaz-Gümüş, 2018, p. 45).

Pym et al. (2012, p. 80) define professionalization as a process covering several organizational and occupational traits at the end of which an occupation upgrades its status. This process principally

Acknowledging that translation is not a full-fledged profession yet, the label translation profession is used in this study as an umbrella term referring to translation and interpreting due to the tendency in TS literature.

Adres $\mid$ Address

RumeliDE Dil ve Edebiyat Araştırmaları Dergisi $\quad$ RumeliDE Journal of Language and Literature Studies

Osmanağa Mahallesi, Mürver Çiçeği Sokak, No:14/8 Osmanağa Mahallesi, Mürver Çiçeği Sokak, No:14/8

Kadıköy - ISTANBUL / TÜRKIYE 34714 Kadıköy - ISTANBUL / TURKEY 34714

e-posta: editor@rumelide.com e-mail: editor@rumelide.com

tel: +90 505 7958124, +90 2167730616 phone: +90 505 7958124, +90 2167730616 
requires the fulfilment of several attributes, namely education facilities for the training of the specialized skill, formation of professional organizations and code of ethics and regulation of minimum fees and salaries. They further clarify the steps for professionalization following Wilensky's (1964) framework and state that in order for an occupation to upgrade its status, the occupation should be done full-time by the workers; it should have its own training institutions founded; professional organizations that help to define the essence of the skills and legal support for the regulation of code of ethics should be established, and control of the borders of the job territory should be present, which helps for the separation of the competent professionals from the incompetent ones ( as cited in Pym et al. 2012, p. 81). In the same way, Godbout (2012) explains critical points in professionalization, using the studies of Wilensky (1964) and Ritzer\& Walczak (1986) and draws an outline of the steps for an occupation to be a full-fledged profession. The core elements of this process may be summarized as follows:

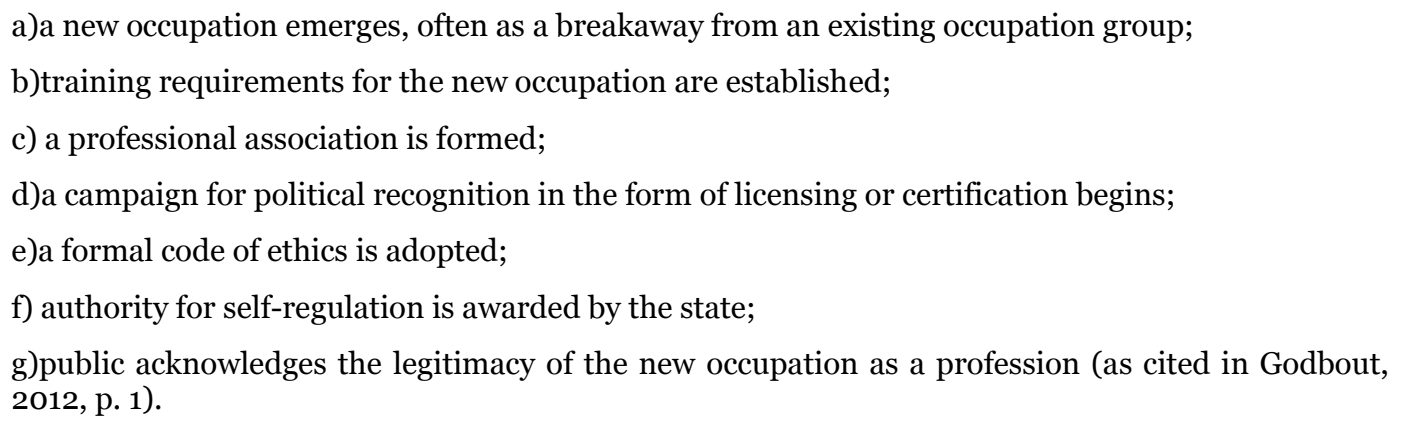

In short, it would not be wrong to assert that all these studies basically focus on similar traits or criteria to define the process of professionalization. The first trait is linked to the acquisition of the required skills to perform the profession, namely education or training facilities. The second trait acknowledged in the previous research is the formation of professional organizations which unite members of the profession. The final trait can be referred to as the regulation mechanism or processes that cover 'the competence of professionals measured by examinations' in Millerson's (1964, as cited in Yllmaz-Gümüss, 2018) classification and 'defining the essence of the skills and legal support for the regulation of code of ethics and control of the borders of the job territory' in the definition of Pym et. al. (2012) or 'the adoption of formal code of ethics and formation of authority for self-regulation awarded by the state' in the framework of Godbout (2012). The scope of the present study is the investigation of the status of the translation profession in Turkey from the perspective of the sociology of professions following these three basic traits, namely education facilities, professional associations and the regulation processes for delineating the borders of the job territory.

\section{An analysis of the status of translation profession in Turkey from the perspective of professionalization}

The professionalization process of translation in Turkey is investigated in this section with a focus on the status of the translator education, professional translator associations, current legislations concerning translators and regulations on translation market in Turkey, and recent developments regarding legal processes for delineating the national standards and borders of the translation profession and the attempts for the establishment of a translator certification system.

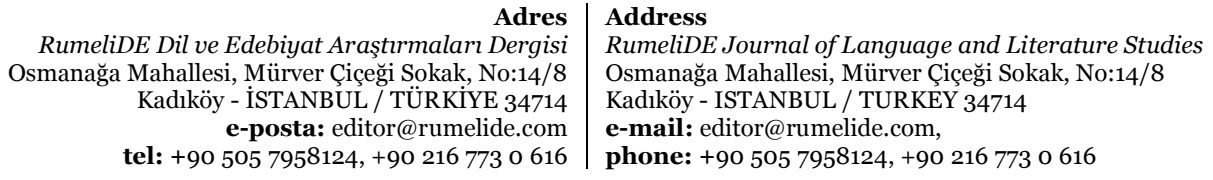

tel: +90 505 7958124, +90 2167730616 


\subsection{Translator education}

The establishment of education based on theoretical knowledge and training of specialized skills and expertise generally emerge as the first trait attributed to professionalization. Godbout (2012, p. 2) further defines this criterion as "work, in the form of a skilled service or advice, performed by members of the profession requires extensive university training in a discipline grounded in a body of knowledge based on theory." Dam\& Zethsen (2011, p. 986) claim that professions requiring a high level of education, expertise or specialized knowledge appear at the top of the prestige scale.

Translation appeared as a branch of science towards the middle of the 1900 s around the world and so did academic translator training (Bildik, 2015, p. 54). In Turkey, translation and interpreting education started as a four-year undergraduate program in 1982 in one of the long-established universities in the country, the Hacettepe University, which was followed by the Boğaziçi University in 1983. The 2020 Guide of the Center for Assessment, Selection and Placement in Turkey lists 49 universities (state and foundation-funded universities combined, Kirghizstan and the Turkish Republic of Northern Cyprus included) offering four-year undergraduate programs of translation and interpreting in several languages, including English, French, German, Russian, Arabic, Chinese, Bulgarian, Farsi and Kirghiz3. Since 2012, associate degrees under the program name 'Applied English/Spanish/Russian and Translation' have also been enlisted in the Guide of the Center for Assessment, Selection and Placement. In addition to offering associate and bachelor degrees, some of the universities also provide master's and doctorate programs. Currently, university-based training is the main and only source of formal workforce provider to the market (PMDGAD 2015, pp. 9-11; Tekgül, 2008, p. 63; Yllmaz-Gümüş, 2018, p. 50).

Although university-based training is the only source of formal workforce for translators and interpreters in Turkey, the unregulated market conditions weaken the role of a university degree in translation as a powerful professional signal for translation graduates. On the other hand the proliferation of translation and interpreting programs may pose a problem on the way to professionalization since the number of graduates may exceed the relative demand on the job market. Over 4.000 graduates are estimated to complete the undergraduate and associate degree programs each year; however, this number seems to be higher than the number of translators employed (YllmazGümüs, 2018: 58). The increasing number of translation and interpreting programs brings about another problem in terms of the quality of translation education. Some of these programs may fail to meet real market demands because of the lack of qualified teaching staff and effective curriculum content, as is mentioned by Öner (2012, pp. 60-61). As globalization and technological developments directly affect the needs of the translation market and shape the profile of the profession, academic programs need to update their program content in accordance with the expectations of the changing market. The significance of designing competence-based translation programs and taking market needs into consideration has been discussed in many studies concerning translator education in Turkey recently (Eser, 2013; Gllıç, 2020; Köktürk\&Türkmen, 2020; Öner-Bulut, 2019; Ören, 2020; Türkmen, 2019), which is promising in terms of the quality of the curriculum content of translation and interpreting programs.

3 The 2020 Guide Of The Center For Assesment, Selection And Placement (n.d.), Consulted on 20 February, 2020. Retrieved from, https://yokatlas.yok.gov.tr/lisans-bolum.php? $\mathrm{b}=11013>$.

Adres $\mid$ Address

RumeliDE Dil ve Edebiyat Araşttrmaları Dergisi $\quad$ RumeliDE Journal of Language and Literature Studies Osmanağa Mahallesi, Mürver Çiçeği Sokak, No:14/8 Osmanağa Mahallesi, Mürver Çiçeği Sokak, No:14/8

Kadıköy - ISTANBUL / TÜRKIYE 34714 Kadıköy - ISTANBUL / TURKEY 34714 e-posta: editor@rumelide.com

e-mail: editor@rumelide.com,

tel: +90 505 7958124, +90 2167730616 phone: +90 505 7958124, +90 2167730616 
An in-depth analysis of the status quo of translation profession in Turkey from the perspective of trait theory of professionalization / N. M. Uysal (pp. 841-860)

\subsection{Professional translator association(s)}

Formation of professional associations (used as a generic term here) is another step in the process of professionalization. Translator associations do not have a long history in Turkey. Table 1 enlists translator associations in Turkey based on the chronological order of establishment. The Conference Interpreters Association of Turkey [Türkiye Konferans Tercümanları Derneği (TKTD)] established in 1969 is the oldest translator association. Adopting the standards and code of ethics of the International Association of Conference Interpreters, TKTD aims at uniting conference interpreters in Turkey and optimizing the quality of working conditions for interpreting (Türkiye Konferans Tercümanları Derneği, n.d.)4.

Established in 1992, The Translators' Association of Turkey [Türkiye Çevirmenler Derneği (TÜÇED)]is a member of the International Federation of Translators (FIT) and one of the oldest associations admitting several categories of members in the translation market. The categories include practicing translators both as individual taxpayers or employees in organizations, translation agency owners and language-related professionals in the tourism sector (Türkiye Çevirmenler Derneği, n.d.)5.

The association has attempted to make some significant contributions to the translation profession, like submission of a bill of law for the establishment of a national chamber of translators to the Grand National Assembly of Turkey, translation profession reports of the PMDGAD and the efforts for the abolishment of the public notary endorsement for translations produced by sworn translators. Recently, the Federation of International Translators and Translation Agencies [Uluslararası Çevirmenler ve Çeviri Kuruluşları Federasyonu (TUÇEF)] was established in cooperation with TÜÇED. The two organizations work cooperatively for similar goals (Uluslararası Çevirmenler ve Çeviri Kuruluşları Federasyonu, n.d.) ${ }^{6}$.

Another association that is a member of FIT is the Translation and Interpreting Association of Turkey [Çeviri Derneği], established in 1999. Membership is open to anyone having professional involvement/experience in any translation field, who is a translator, interpreter, academician, proofreader, a translation company owner or publisher (Çeviri Derneği, n.d.) ${ }^{7}$.

The one and only association having the authority to uphold the rights of members within the law is the Translators' Association of Turkey [Çevirmenler Meslek Birliği (ÇEVBİR)], established in 2006. It is one of the 27 legally-established professional associations in Turkey. ÇEVBIR is a member of the European Council of Literary Translators' Association (CEATL) and principally works for improving the status and working conditions of literary translators and setting up ethical principles in the publishing industry (Çevirmenler Meslek Birliği, n.d.) ${ }^{8}$.

\footnotetext{
4 Türkiye Konferans Tercümanlari Derneği [The Conference Interpreters Association of Turkey]. (n.d.). Consulted on 22 February, 2020, Retrieved from, https://www.tktd.org/ ürkiye Çevirmenler Derneği [The Translators' Association of Turkey]. (n.d.). Consulted on 22 February, 2020,. Retrieved from, http://www.tuced.org.tr/

Uluslararası Çevirmenler ve Çeviri Kuruluşları Federasyonu. [Federations of International Translators and Translation Agencies] (n.d.) Consulted on 22 February, 2020. Retrieved from, http://www.tucef.org/.

Çeviri Derneği [The Translation and Interpreting Association of Turkey]. (n.d.). Consulted on 26 February, 2020. Retrieved from, <http://www.ceviridernegi.org/

Çevirmenler Meslek Birliği [Translators' Association of Turkey]. (n.d.). Consulted on 26 February, 2020. Retrieved from, http://cevbir.org.tr/ 
The Association of Playwrights and Translators [Oyun Yazarları ve Çevirmenleri Derneği (OYÇED)] was established in 2006. OYÇED intends to observe the rights of playwrights and translators and increase the popularity of theatre in Turkey (Uysal 2017, pp. 143,144).

The Association of Translation Companies [Çeviri Işsletmeleri Derneği (Çi̇D)] was established in 2007 and is a member of the European Union of Association of Translation Companies (EUATC). ÇID acts as an umbrella organization for the translation companies in Türkiye çíD has initiated several important projects like Academy-Sector Cooperation Project, Director School Program and Human Resources Development Program for the improvement of the translation market and increasing the quality standards of the translation companies in Turkey. Academy-Sector Cooperation Project is aimed at strengthening the connection between academic institutions and translation market. Members of the association has visited translation and interpreting programs around the country and given seminars on various topics within the project (Türkiye Çeviri İşletmeleri Derneği, n.d.)9.

The Certified Translation Federation [Yeminli Çevirmenlik Federasyonu (TURÇEF)] was founded in 2014 and is an umbrella federation for several regional agencies and local translation offices. Like TÜÇED and TUÇEF, it carries out projects for the regulations on the translation market such as removing the Public Notary Endorsement on legal documents (Yeminli Çevirmenlik Federasyonu, n.d. $)^{10}$.

Conker (2020, p. 56) states that there are three associations of sign language interpreters in Turkey. The Association of Sign Language Interpreters [İşaret Dili Tercümanları Derneği (IDTD)] is the oldest association founded in 2010. It is a member of The World Association of Sign Language Interpreters (WASLI) and The European Forum of Sign Language Interpreters (EFSLI). The association has prepared a code of ethics that is in accordance with those of WASLI and EFSLI. The other associations are The Association of Sign Language and Sign Language Interpreters [İşaret Dili ve Tercümanları Derneği (TIDTED) ${ }^{11}$ founded in 2016, and The Association for the Deaf, Sign Language Interpreters and Trainers [İşitme Engelliler İşaret Dili Tercümanları ve Eğitmenleri Derneği (İEİDTED)] founded in $2017^{12}$.

Finally, The Turkish Union of Translation Students [Türkiye Çeviri Öğrencileri Birliği (TÜÇEB)] was founded in 2010 and has united the students of the translation and interpreting departments all around the country. TÜÇEB has been organizing workshops focusing on specific themes. These organizations give the learners of different translation and interpreting programs the opportunity of sharing ideas on various topics as future translators (Türkiye Çeviri Öğrencileri Birliği, n.d.)13.

As a result, sufficient numbers of translator associations have been established to improve the status of the profession and advocate the rights of translators working in various fields of translation in Turkey. However, when the total number of translators (approximately over 10.000) is taken into consideration, the number of translators represented by these associations seems to be low. This was

Çeviri İşletmeleri Derneği [The Association of Translation Companies]. (n.d.). Consulted on 26 February, 2020,. Retrieved from, https://cid.org.tr/

Yeminli Çevirmenlik FederasyonU [The Certified Translation Federation]. (n.d.). Consulted on 26 February, 2020, Retrieved from, https://www.turcef.net/

şaret Dili ve Tercümnaları Derneği [The Association of Sign Language and Sign Language Interpreters] (n.d.). Retrieved from, http://www.tidted.org/

İşitme Engelliler İşaret Dili Tercümanları ve Eğitmenleri Derneği [The Association for the Deaf, Sign Language Interpreters and Trainers](n.d.). Retrieved from, http://www.ieid.org.tr/index.html

Türkiye Çeviri Öğrencileri Birliği [The Turkish Union of Translation Students]. (n.d.). Consulted on 22 February, 2020. Retrieved from, http://tuceb.org/

RumeliDE Dil ve Edebiyat Araşttrmaları Dergisi Osmanağa Mahallesi, Mürver CCiçeği Sokak, No:14/8 Kadıköy - ISTANBUL / TÜRKIYE 34714 e-posta: editor@rumelide.com tel: +90 $5057958124,+902167730616$
Address

RumeliDE Journal of Language and Literature Studies

Osmanağa Mahallesi, Mürver Çiçeği Sokak, No:14/8

Kadıköy - ISTANBUL / TURKEY 34714

e-mail: editor@rumelide.com,

phone: +90 $5057958124,+902167730616$ 
An in-depth analysis of the status quo of translation profession in Turkey from the perspective of trait theory of professionalization / N. M. Uysal (pp. 841-860)

also reported by Pym et al. (2012). Eruz (2012, p. 18) highlights the necessity and importance of increasing the number of members of the translation associations to strengthen translator associations' potential and power in the translation market.

\begin{tabular}{|c|c|c|c|}
\hline $\begin{array}{l}\text { Name of the } \\
\text { organization }\end{array}$ & Year of establishment & $\begin{array}{l}\text { Membership of a } \\
\text { wider organization }\end{array}$ & $\begin{array}{l}\text { Aims to bring } \\
\text { together }\end{array}$ \\
\hline $\begin{array}{l}\text { The Conference } \\
\text { Interpreters Association of } \\
\text { Türkiye (TKTD) }\end{array}$ & 1969 & - & conference interpreters \\
\hline $\begin{array}{l}\text { The Translators' } \\
\text { Association of Türkiye } \\
\text { (TÜÇED) }\end{array}$ & 1992 & FIT & $\begin{array}{l}\text { translators and } \\
\text { translation agencies }\end{array}$ \\
\hline $\begin{array}{l}\text { The Federation of } \\
\text { International Translators } \\
\text { and Translation Agencies } \\
\text { (TUÇEF) }\end{array}$ & & & $\begin{array}{l}\text { in cooperation with } \\
\text { TÜÇED, established as a } \\
\text { federation to bring } \\
\text { together local and } \\
\text { national translator } \\
\text { associations }\end{array}$ \\
\hline $\begin{array}{l}\text { The Translation and } \\
\text { Interpreting Association of } \\
\text { Türkiye }\end{array}$ & 1999 & FIT & $\begin{array}{l}\text { all actors of professional } \\
\text { involvement in } \\
\text { translation }\end{array}$ \\
\hline $\begin{array}{l}\text { The Translators' } \\
\text { Association of Türkiye } \\
\text { (ÇEVBIR) }\end{array}$ & 2006 & CEATL & $\begin{array}{l}\text { holders of a translated } \\
\text { work covered by the law } \\
\text { on Intellectual Property } \\
\text { Rights }\end{array}$ \\
\hline $\begin{array}{l}\text { The Association of } \\
\text { Playwrights and } \\
\text { Translators (OYÇED) }\end{array}$ & 2006 & - & $\begin{array}{l}\text { holders of a play, } \\
\text { translation or adaptation } \\
\text { of a play }\end{array}$ \\
\hline $\begin{array}{l}\text { The Association of } \\
\text { Translation Companies } \\
\text { (ÇiD) }\end{array}$ & 2007 & EUATC & translation companies \\
\hline $\begin{array}{l}\text { The Turkish Union of } \\
\text { Translation Students } \\
\text { (TÜÇEB) }\end{array}$ & 2010 & - & $\begin{array}{l}\text { translation and } \\
\text { interpreting students }\end{array}$ \\
\hline $\begin{array}{l}\text { The Association of Sign } \\
\text { Language Interpreters } \\
\text { (IDTD) }\end{array}$ & 2010 & $\begin{array}{l}\text { WASLI } \\
\text { EFSLI }\end{array}$ & $\begin{array}{l}\text { sign language } \\
\text { interpreters }\end{array}$ \\
\hline $\begin{array}{l}\text { The Certified Translation } \\
\text { Federation (TURÇEF) }\end{array}$ & 2014 & - & $\begin{array}{l}\text { regional agencies } \\
\text { representing local } \\
\text { translation agencies }\end{array}$ \\
\hline $\begin{array}{l}\text { The Association of Sign } \\
\text { Language and Sign } \\
\text { Language Interpreters } \\
\text { (TIDTED) }\end{array}$ & 2016 & - & $\begin{array}{l}\text { sign language } \\
\text { interpreters }\end{array}$ \\
\hline $\begin{array}{l}\text { The Association for the } \\
\text { Deaf, Sign Language } \\
\text { Interpreters and Trainers } \\
\text { (IEIDTED) }\end{array}$ & 2017 & - & $\begin{array}{l}\text { sign language } \\
\text { interpreters and trainers }\end{array}$ \\
\hline
\end{tabular}

Table 1: Translator associations in Turkey in chronological order of establishment

\begin{tabular}{|c|c|}
\hline Adres & Address \\
\hline RumeliDE Dil ve Edebiyat Ara & RumeliDE Journal of Language and Literature Studies \\
\hline smanağa Mahallesi, Mürver Cic & Osmanağa Mahallesi, Mürver Çiçeği Sokak, No:14/8 \\
\hline $\begin{array}{r}\text { Kadıköy - İSTANBUL / TÜRKIYYE } 34714 \\
\text { e-posta: editor@rumelide.com } \\
\text { tel: +90 505 7958124, +90 } 2167730616\end{array}$ & $\begin{array}{l}\text { Kadıköy - ISTANBUL / TURKEY } 34714 \\
\text { e-mail: editor@rumelide.com, } \\
\text { phone: +90 505 7958124, +90 } 216773 \text { o } 616\end{array}$ \\
\hline
\end{tabular}




\subsection{A general overview of the translation market in Turkey in terms of current legislations and regulations}

Taking a general look at the translation industry in Turkey on the basis of current legislations and regulations will be helpful to better analyze the current situation of the translation profession. The Prime Ministry Directorate General for Administration Development (PMDGAD) has published two reports $(2011,2015)$ giving information on the translation profession and industry in Turkey. According to the 2015 report, the size of the translation industry in the country is about 800 million dollars, and the number of "qualified translators" is around 10.000 (approximately 20.000 people are estimated to be engaged in doing translation though not as a full-time occupation), 2.500 of them are employed in civil service, and the number of interpreters is roughly 3000.

There are a number of legislations involving translators. These entail

a) Turkish Criminal Law Nr 5237;

b) Code of Civil Procedure Law Nr. 6100;

c) The Law on Intellectual Property Rights;

d) Notary Public Regulations.

The Turkish Criminal Law Nr. 5237 includes expertise or interpretation contrary to truth; the related article is as follows:

ARTICLE 275-(1) In case of declaration of opinion contrary to the truth by the expert(s) appointed by the judicial bodies or person(s) or a committee authorized to carry out legal investigation or hear witnesses under oath; the offender is punished with imprisonment from one year to three years.

(2) The provisions of the first subsection are applied in case of false interpretation of statements or documents by an interpreter who is appointed by the person(s) or a committee mentioned in the first subsection" (Turkey-Legal Gazette, 2004, article 275; emphasis added).

One other legislation is the Code of Civil Procedure Law Nr. 6100. Article 263(1) and (2) of the Code of Civil Procedure Law Nr. 6100 involve the conditions in which an interpreter is assigned in courts: if the witness does not know Turkish, he testifies through an interpreter, and if the witness is deaf, mute and illiterate, he testifies through a sign language expert. As with the related article of the Turkish Criminal Law, Article 375 (1-f) enlists "a deliberate declaration of opinion to the truth by the expert or the interpreter" as one of the reasons for reopening of proceedings (PMDGAD 2015, 22-23; emphasis added $\left.{ }^{14}\right)$.

The Law on Intellectual Property Rights appeals to the protection of translated works and rights of translators because the law accepts translated works as the unique results of a creative activity just like authors' works, and translators' rights and works are protected just like authors' within the law (Esteves 2005, para.1; Tahir-Gürçağlar, 2011, p. 85).

Although the Law on Intellectual Property Rights seems to observe translators' rights as owners of creative works, it may pose a challenge for translators in certain cases. Translators may face some contradictory situations depending on related articles of the Turkish Criminal Code and the Press Law. In cases when the original work includes "criminal" or "illegal" content and when the author is abroad

14 Translations are mine unless otherwise attributed. 
An in-depth analysis of the status quo of translation profession in Turkey from the perspective of trait theory of professionalization / N. M. Uysal (pp. 841-860)

or not subject to Turkish laws, translators may be prosecuted as the owners of the work, which causes reactions of some of the translator associations in Turkey (Çeviribilim 2006, para. 5).

The last legislation to be discussed is the Notary Public Regulations. Article 96 of the regulation calls for the requirements to become a sworn translator and the registration of sworn translators in notaries. In Turkey, the only way to become a sworn translator is taking an oath before a notary public. Translations are only considered official with the signature of the notary's sworn translator together with the notary stamp. Only Turkish citizens can become sworn translators; therefore, there is no need to prove fluency in Turkish. On the other hand, candidates have to officially present their knowledge of the foreign language, either with a diploma or other documents accepted by the notary. A notary can only work with registered translator(s). Pym et al. (2012, pp. 25-26) explain the ways translated documents are officially certified around the world. In some countries, the state administrative institutions test translators, and the ones passing the test can deserve the title "sworn" or "authorized"; yet, in some others, only educational qualifications or translator certification act as a marker to receive the title. In Turkey, being a translation and interpretation graduate is not a requirement to be a sworn translator and the professional qualifications of the applicant who wants to be a sworn translator are not evaluated on the basis of an assessment system testing translation competence. As a result, the notary system in sworn translation is criticized (Uysal, 2020).

As a sub-field of sworn translation, legal translators, who will participate in the translation procedures of the judicial system, also have to take an oath before the justice commission of a province court. These translators are registered on a list, and this way, they become entitled to do translations in courts, police departments and land registry offices of the related province (Hanisch, 2017, para.1-3).

Although parts of these laws/codes involve translators, obviously they are limited in scope and are not aimed at meeting sector needs. The most salient problems the translation industry and translators face in Turkey may be exemplified as low-pricing, lack of solidity, unregulated market conditions (especially, freelance translators who are forced to work non-contractual and invoice-free) and inefficient employee personal rights for translators at government institutions. The lack of certification or other signals for earning credibility on the market also have negative effects for translators (YllmazGümüs, 2018, p. 60). The absence of relevant regulations, regulation authority/ies for translators and related certification procedures are claimed to be the main reasons for these problems (Bildik, 2015, p. 136; Ersoy\& Erkurt, 2014, p. 133; Küçükyağcı \& Avcı, 2011, pp. 30-33; Uysal, Odacıŏlu \& Köktürk, 2015, pp. 262-263).

On the other hand, there have been a number of significant attempts in increasing the credibility of the profession and regulating the market in the last decade. One of them is a bill of law submitted to the Grand National Assembly of Turkey, which was prepared by the contributions of some translator associations (Yllmaz-Gümüş, 2018, p. 51) (see sub-section 3.4 for a more in-depth description of the bill of law).

Presence of a translators' chamber would solve an outstanding problem resulting from the absence of a specific regulation. In order to establish a translation company/office, application to the local Chamber of Commerce is a requirement; no other requirement/criterion related with translation facilities is sought for currently. This brings about unregistered translation offices (Kobya\& Karabacak, 2015). The establishment of a translators' chamber is expected to lead to a degree of control over market entry.

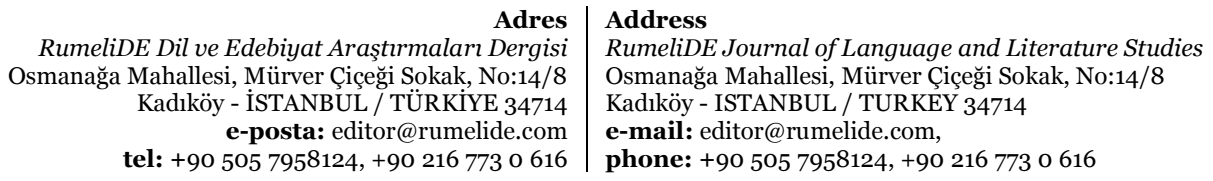


Another important contribution came from the VQI. Thanks to the Coordination Group initiated by the VQI, the National Professional Standard for Translators/Interpreters was introduced in 2013, which was developed into the draft versions of national qualifications for specific fields of translation. The next step will be the advent of certification procedures. As this applies to an essential attribute of professionalization, the establishment of legal guidelines delineating the standards and territory of the profession, this development will be dealt with in more detail in the following section (Sub-section 3.4).

\subsection{Recent legal processes for delineating the borders of the translation profession territory}

Linked to the attribute of regulation processes for the translation profession, recent works of VQI for translation profession within the NVQS should be mentioned as attempts to delineate the borders of the profession by establishing the national standards and qualifications for the profession and the translator certification system. Millerson (1964, as cited in Yllmaz-Gümüş, 2018) mentions the essence of evaluation of the competence of professionals measured by examinations. Pym et. al. (2012) highlights the importance of specifying the required skills to perform the job and establishment of the legal support for the regulation of the code of ethics and control of the borders of the job territory. Similarly, Godbout (2012, p. 5) briefly defines this criterion as "the establishment of a legal authority to control access to the profession." When such organizing body is formed, it is expected that standards of performance for the profession are enforced by a governing body that has the power to decide who is admitted to the profession; in this way, a degree of market control could be achieved.

As mentioned in Section 3.3., the translation market is not controlled by any legal authority in Turkey currently and is open to anyone speaking a foreign language (Yllmaz-Gümüş, 2018, p. 51), which is the case for most countries (Katan, 2009). The lack of such a legal authority has been accepted as one of the most critical problems the translation market in Turkey is facing today. In 2012, a bill of law concerning the establishment of national and local chambers of translators was submitted to the Grand National Assembly of Turkey. With the legal status and jurisdiction they possess, professional chambers differ from other professional associations in Turkey. They can act as the legal authority to impose sanctions. Therefore, the establishment of a translators' chamber is believed to have a critical role in the regulation of the translation market in Turkey, acting as a gatekeeper to decide who will or will not be admitted in terms of natural and legal persons, improving working conditions of translators in different fields and protecting their rights legally, and taking measures for ethical conduct, etc. (PMDGAD 2015, p. 51; Uysal, 2017a, p. 148; Yllmaz-Gümüş, 2018, p.52).

Although there has not been noteworthy progress since the submission of the bill of law for a translators' chamber, there have been some recent developments in terms of delineating the borders of the job territory: the inclusion of the translation profession within the NVQS of the VQI and the establishment of certain legal instruments as a result of this regulation process.

VQI was set up as a state-awarded institution in 2006 to organize a NVQS compatible with the European Union (EU). VQI briefly defines the scope of the qualification system as follows:

Having a national qualifications system that enhances the quality of education and training and strengthens the link between education and employment is among the priority needs for Turkey. Therefore, Turkey is committed to providing the Turkish Qualifications Framework which will be in harmony with the European Qualifications Framework (EQF) and will also meet the education and

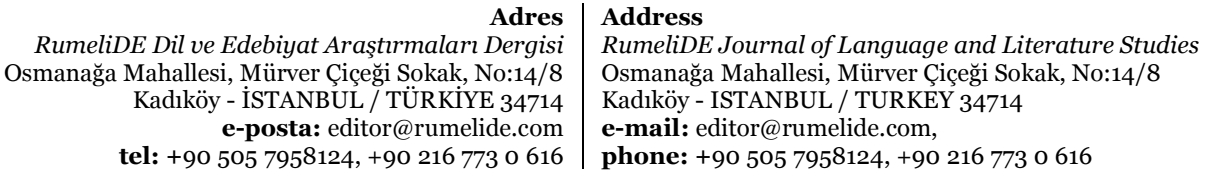

tel: +90 505 7958124, +90 2167730616 
An in-depth analysis of the status quo of translation profession in Turkey from the perspective of trait theory of professionalization / N. M. Uysal (pp. 841-860)

training needs of all individuals through lifelong learning support and ensure the development of qualifications required by the labour market (VQI 2015a, i).

To achieve reliable certification systems, a three-stage process, which is maintained with the contributions of various stakeholders related to the professions, is followed. The process may essentially be summarized as the establishment of the National Professional Standards, the National Qualifications, and the Certification Procedures for an occupation or a profession, respectively (Uysal 2017a, pp. 155-162). The EQF is used as a reference tool in the process of developing the National Professional Standard and the National Qualifications. One of the most important strengths of this system is that it aims to encompass personal qualifications that have been gained in various types of learning contexts, formal education, non-formal education and all types of lifelong learning procedures. This feature of the system complies with one of the EU policies, encouraging citizens for lifelong learning. Another significant feature of the system is that the EQF has been used as a reference point in forming both the standard and the qualifications. This will allow for the comparison of certificates with qualification systems of other countries and international mobility for professionals. That is why the system is expected to go beyond national boundaries (VQI, n.d., p. 4).

The NVQS and the legal instruments formed within this system are evaluated as a response to the attribute of the legal regulations in this study in two ways: First, the National Professional Standard and the National Qualifications documents can be regarded as the legal instruments delineating the required skills to perform the job. Second, establishing a certification system can act as an evaluation system for the competence of professionals (which is mentioned in Millerson's definition, 1964). That way, the standards of performance could be established, which in turn may act as a control mechanism for the borders of the job territory (which is provided in the classifications of Pym et al., 2012 and Godbout, 2012).

\subsubsection{The legal instruments for the establishment of the national standards and qualifications of translation profession}

Godbout (2012, pp. 2, 5) mentions the necessity of an entity delegated by the state to control access to the profession and adds that members of the profession should constitute this entity so that they can control the criteria for admission to the profession. The most common way to set a threshold for admission to the profession is through licensing or certification, the latter generally being a voluntary, non-exclusive practice. In this respect, it would not be wrong to say that VQI bridges the very gap concerning the regulation and certification procedures for the translation market in Turkey. VQI included the translation profession in its list of professions to be integrated into the NVQS in 2012, and initial works for the development of the National Professional Standard for Translators/Interpreters started with the contributions of the Coordination Group, including representatives of different stakeholders in the translation market in Turkey like academics from university-based translation programs, translator associations, leading state institutions employing translators and translation companies. In January 2013, the standard was introduced (VQI, 2015b). Table 2 illustrates the basic components of the National Professional Standard for Translators/Interpreters.

Translation profession is situated at level 6 of the EQF in the National Professional Standard for Translators/Interpreters. The standard does not differentiate translation and interpretation or their subfields because it is aimed at applying to the general basics of both fields.

Adres $\mid$ Address

Osmanağa Mahallesi, Mürver Çiçeği Sokak, No:14/8 Osmanağa Mahallesi, Mürver Çiçeği Sokak, No:14/8

Kadıköy - İSTANBUL / TÜRKIYE 34714 Kadıköy - ISTANBUL / TURKEY 34714 e-posta: editor@rumelide.com

tel: +90 505 7958124, +90 2167730616 phone: +90 505 7958124, +90 2167730616 


\begin{tabular}{|l|}
\hline The Standard is basically comprised of the following categories: \\
\hline Description of the profession \\
Definition of the profession \\
Position of the profession in international classification systems \\
Regulations related to health, security and environment \\
Other legislation related to the profession \\
Working environment and conditions \\
Other requirements related to the profession \\
\hline Profile of the profession \\
Duties, procedures and performance criteria \\
Tools, instruments and equipment used \\
Knowledge and skills \\
Attitudes and behaviors \\
\hline Measurement, assessment and certification \\
\hline
\end{tabular}

Table 2: The components of the National Professional Standard for Translators/Interpreters in Turkey

Following the establishment of the standard, the draft versions of the National Qualifications for Liaison Interpreting, Conference Interpreting, Community Interpreting, Sign Language Interpreting, Specialized Translation and Localization were announced by the VQI in January 2019. When the drafts are finalized, a certification system for the above-mentioned fields of translation will be developed on the basis of the agreed qualifications. Table 3 indicates the main components of the National Qualifications for Specialized Translation as an example.

Qualification Title: The National Qualification for Specialized Translation

The Reference Code: $18 \mathrm{UYXxx}-6$

Level (according to EQF): 6

Purpose: The purpose of this national qualification is to define necessary qualifications, knowledge, skills and competencies the candidates should possess, to give candidates the opportunity to certify their professional qualifications through a valid and reliable certificate and to be a reference point for the higher education system and examination and certification institutions, thereby increasing the quality in the profession.

The Qualification is based on the National Professional Standard for Translators/Interpreters (Level 6)

Entry Requirements: $\mathrm{C} 1$ level (according to the CEFR) in the target language. The candidate is also expected to choose from a number of subfields suggested (e.g. Science, Maths, Architecture...or Language, Culture, Philosophy...or Law, International Relations, Management and etc.) and submit a dossier including work experience and qualifications.

The Structure of the Qualification (Compulsory or/and Voluntary Units and Grouping Alternatives for Those Units): There are3 compulsory units for specialized translation

A1: Occupational Health and Safety

A2: Work Organization and Preparation for Translation

A3: Translating a Document, Checking and Assessing One's Own Translation

Assessment and Evaluation: Section A1 can be done in a separate session but A2 and A3 must be done successively. A certificate of success for each and every section, valid for 6 months, is given but in order to receive "Specialized Translator Certificate" the candidate is expected to succeed all sections.

Certificate Validity Period: 5 years for all qualifications

Inspection Procedure: The translator is subjected to an inspection at the end of the second year s/he has received the certificate.

Renewal Procedure for the Certificate: The translator is expected to submit a required document showing his/her

\section{Adres $\mid$ Address}

RumeliDE Dil ve Edebiyat Araştırmaları Dergisi $\quad$ RumeliDE Journal of Language and Literature Studies Osmanağa Mahallesi, Mürver Çiçeği Sokak, No:14/8 Osmanağa Mahallesi, Mürver Çiçeği Sokak, No:14/8

Kadıköy - ISTANBUL / TÜRKIYE 34714 Kadıköy - ISTANBUL / TURKEY 34714

e-posta: editor@rumelide.com e-mail: editor@rumelide.com,

tel: +90 505 7958124, +90 2167730616 phone: +90 505 7958124, +90 2167730616 
An in-depth analysis of the status quo of translation profession in Turkey from the perspective of trait theory of professionalization / N. M. Uysal (pp. 841-860)

work performance in this 5-year period, ensuring mandatory professional development and continuing competence of members of the profession.

Contributory Institutions for Developing the Qualification: Generally, names of universities and professional associations taking part in the process of developing the qualification are included in this part.

The Sector Committee Verifying the Qualification: The related committee of the VQI is included in this part.

Table 3: The components of the National Qualification for Specialized Translation (Draft Version), VQI (2018)

\title{
3.4.2. Translator certification procedures within NVQS
}

The final step of the NVQS is the accreditation of certifying bodies. Certifying bodies can be defined as the institutions accredited by the Turkish Accreditation Agency within "EN ISO/IEC 17024:2012General requirements for bodies operating certification of persons” standard and approved by VQI (VQI, 2015a, p. 6). VQI defines this certification process as

\begin{abstract}
Bodies with TS EN ISO/IEC 17024 accreditation, which comply with the required criteria, are assigned by the VQI as "Authorized Awarding Bodies" to undertake assessment, evaluation and certification activities for the national qualifications. Authorized Awarding Bodies assess the individuals who wish to be awarded a VQI Vocational Qualification Certificate in the relevant qualification and issue certificates for those who become successful (VQI, 2015a, p. 7).
\end{abstract}

When assessment and evaluation procedures of different qualifications are analyzed, it can be argued that the system is designed to make a comprehensive evaluation of several translation subcompetencies. To illustrate (see Table 3 above), unit A2 in the National Qualification of Specialized Translation consists of two tasks: 'Making a work organization' and 'Making a preparation for the translation'. In this unit, candidates are expected to define the types and functions of the texts they were introduced to, possible semantic shift units in these texts, whether they will need to use footnote strategy, express and exemplify the information they will need in the translation process, produce a related terminology list and explain the term translation memory, its function, use and importance for the translation work. In addition to these, candidates are required to explain the steps of the work organization and justify their choices during the process.

In Unit A3, which covers the tasks of 'translating a document' and 'checking and assessing one's own translation', candidates are required to produce a coherent and comprehensive translated text in accordance with the specialized area, purpose of translation and target language. Since the use of computer-assisted translation tools is allowed, they should be able to demonstrate an adequate performance in using these tools and state all types of resources they refer to during the test. Moreover, being able to make justifications for translation strategies used while translating is a significant marker for the assessment. Therefore, candidates should be able to explain and exemplify problems they have coped with during the translation process, such as terminology problems, problems in analyzing the text, units/parts where more than one translation alternatives could be used. Additionally, they should be able to express part(s) of the text they have difficulty in translating due to the information gap and what solutions they can offer to come up with the problem and for which parts consulting a reviewer is essential.

\section{Discussion and conclusion}

The present article has discussed the degree of professionalization of translation on the basis of the sociology of professions, which covers the attributes that an occupation should exhibit in order to be a full-fledged profession. The attributes of professionalization covered in this study are the

\section{Adres $\mid$ Address}

RumeliDE Dil ve Edebiyat Araşttrmaları Dergisi $\quad$ RumeliDE Journal of Language and Literature Studies Osmanağa Mahallesi, Mürver Çiçeği Sokak, No:14/8 Osmanağa Mahallesi, Mürver Çiçeği Sokak, No:14/8 Kadıköy - İSTANBUL / TÜRKIYE 34714 Kadıköy - ISTANBUL / TURKEY 34714 e-posta: editor@rumelide.com tel: +90 505 7958124, +90 2167730616 phone: +90 505 7958124, +90 2167730616 
establishment of education facilities, translator associations, and legal regulations that help to delineate the standards of the profession and the borders of the territory of the profession.

The recent report on translation profession (PMDGAD, 2015, pp. 50-51) states that the size of the translation industry around the world is 15 billion dollars and the translation market in Turkey receives a share of 800 million dollars (including translation in civil service, private sector and EU acquis) out of this global sum. Especially, with globalization and increasing economic, political and cultural relations, the translation industry in Turkey has been proliferating. Therefore, the need for the translation profession and qualified translators is becoming more and more evident and Turkey seems to be a promising country on the way to the professionalization of translation.

Turkey has well-established university-based translation and interpreting programs, offering associate, bachelor, master's and doctorate degrees in several language combinations. However the increasing number of translation and interpreting programs may pose a problem on the way to professionalization because the number of graduates may exceed the relative demand on the job market. Furthermore the number of qualified teaching staff should be increased through wellestablished graduate programs and the curriculum content should be updated and developed in accordance with the new demands of the job market.Universities are the only licensing bodies with the authority to give a certificate of translation and interpreting currently, but market regulations should be strengthened in order to increase the effect of academic training as a signalling device for translation and interpreting graduates.

The presence of several translator associations, representing translators in different fields (though the number of members seems to be low) and translation companies and agencies show that the attribute of the formation of professional associations has been met successfully in Turkey. All these associations are organized on the basis of a specific code of ethics, and they all work for improving the status of the profession and advocating the rights of translators; yet, in the absence of a legally recognized umbrella organization (generally, under the name of a chamber, federation or union) which controls access to the profession, establishes the code of conduct members of the profession are expected to obey, holds the power of imposing sanctions in a breach of ethics and works as an appeal mechanism to solve the problems of translators, the translation profession seems to be far away from being a full profession. As Katan (2009, p. 113) also puts forward, the translation profession is "almost totally unregulated"; therefore, anyone can practice the trade; there is no agreed or policed (national/international) professional code of conduct or quality control, and there is no one practicing body or association to refer concerning the translator and translation profession. Lack of a translators chamber or guild seems to be the main challenge for the professionalization of translation as claimed in numerous studies (Kang, 2015; Kang\& Shunmugam, 2014; Kafi et. al. 2018; Setton\& Liangliang 2011). Like in most other countries, such an organization does not exist in Turkey; consequently, it may be concluded that the attributes of the presence of a state-awarded self-regulation authority is not fully applicable yet.

However, there is a state-awarded organization responsible for regulating the national standards, qualifications, and certification procedures of the profession. The necessity of establishing a certification system for the professionalization of translation has been discussed in many studies (Budin 2013; Chan 2008, 2013; Pym et. al. 2012; Uysal 2015, 2017a, 2017b). VQI has been working for the implementation of a NVQS with the aims of increasing the quality of the workforce, setting standards to evaluate members of a profession, and certifying competencies of individuals gained in

\section{\begin{tabular}{r|r} 
Adres & Address \\
RumeliDE Dil ve Edebiyat Arastırmalar Dergisi & RumeliDE
\end{tabular}}

Osmanağa Mahallesi, Mürver Çiçeği Sokak, No:14/8 Osmanağa Mahallesi, Mürver Çiçeği Sokak, No:14/8

Kadıköy - İSTANBUL / TÜRKIYE 34714 Kadıköy - ISTANBUL / TURKEY 34714

e-posta: editor@rumelide.com

e-mail: editor@rumelide.com

tel: +90 505 7958124, +90 2167730616 phone: +90 505 7958124, +90 2167730616 
An in-depth analysis of the status quo of translation profession in Turkey from the perspective of trait theory of professionalization / N. M. Uysal (pp. 841-860)

different learning contexts. Within the system of VQI, the basic standards for the translation profession and qualifications for members of the profession in the areas the sector is primarily in need of such as specialized translation, localization, community interpreting, conference interpreting, liaison interpreting and sign interpreting have been developed. The next step in the process will be the accreditation of certifying institutions and training institutions (universities), and this will be followed by the formation of the certification system for several subfields of translation based on the qualification documents.

For Turkey, there is still a way to go for translation to be a full-fledged profession. On the other hand, there has been considerable progress to improve the translation profession in recent years. It seems that establishment of regulative authorities and regulations that specify the needs of translators, translation industry and entry to the market and development of a certification system are the keys for the professionalization of translation. Above all, there is a need for the cooperation of all stakeholders to overcome these deficiencies. Translator associations, translator-training institutions, translation service providers, translation users, legislators and other stakeholders should work together on the way to the professionalization of translation.

This study presents qualitative data on the status of the translation profession in Turkey, making an in-depth analysis by considering the the traits of the professionalization process in the sociology of professions. Further research may include ways to manage the cooperation of stakeholders to help improve working conditions of translators, protect their rights, and raise awareness of the profession and implications to overcome the obstacles on the way to the professionalization of translation.

\section{References}

Abraham-Barna, C. G. \& Abraham-Barna, T. (2016). Current trends in the translation market. Studii de Ştiintaşi Cultura, 12(3), 33-44. Retrieved from, https://www.ceeol.com/search/articledetail id $=430163$.

Arı, S. (2014). Çeviri Sosyolojisi. İstanbul: Aylak Adam.

Bildik, C. (2015). Akademik çeviri eğitimi ve çevirmen Yeterlilikleri (Master's Thesis). University of İstanbul, İstanbul, Turkey.

Budin, G., Krajcso, Z., \& Lommel, A. (2013). The transcert project: ensuring that transnational transator certification meets stakeholder needs. Translation and Interpreting, 5(1), 143- 155. Retrieved from, http://www.transint.org/index.php/transint/article/view/237.

Chan, A. L. J. (2008). Information economics, the translation profession and translator certification (Doctoral thesis). University of Rovira i Virgili, Tarragona, Spain.

Chan, A. L. J. (2013). Signal jamming in the translation market and the complementary roles of certification and diplomas in developing multilateral signaling mechanisms. Translation and Interpreting, 5(1), 211-221. Retrieved from, http://www.transint.org/index.php/transint/issue/view/21.

Chesterman, A. (2009). The Name and Nature of Translation Studies. Hermes- Journal of Language and Communication Studies, 42, 13-22. Retrieved from, https://doi.org/10.7146/hjlcb.v22i42.96844.

Conker, N. (2020). Sign language interpreting in the Turkish public service domains in the $21^{\text {st }}$ century. Journal of Translation Studies, 29, 42-60. Retrieved from, https://dergipark.org.tr/tr/download/article-file/134680o.

Çeviribilim (n.d.) Çevirmen yargılama ilkelliğine son verilsin [Blog post]. Consulted on February 20, 2020. Retrieved from, http://ceviribilim.com/?p=336>.

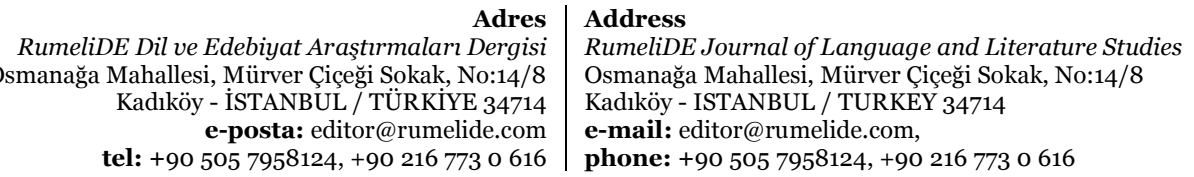


Dam V. H. \& Zethsen, K. K.. (2016). "I think it is a wonderful job” - On the solidity of the translation profession. The Journal of Specialized Translation, 25. Retrieved from, https://www.jostrans.org/issue25/art_dam.php.

Dam V. H. \& Zethsen, K. K. (2008). Translator status: A study of Danish company translators. The Translator, 14(1), 71-96. Retrieved from, https://www.tandfonline.com/doi/abs/10.1080/13556509.2008.10799250.

Dam V. H. \& Zethsen, K. K. (2009). Who said low status: A study on factors affecting the perception of translator status. The Journal of Specialized Translation, 12, 2-36. Retrieved from, https://www.jostrans.org/issue12/art_dam_zethsen.pdf

Dam V. H. \& Zethsen, K. K. (2011). The status of professional business translators on the Danish market: A comparative study of company, agency and freelance translators. Meta, 56(4), 976997. Retrieved from, https://www.erudit.org/fr/revues/meta/2011-v56-n4meta0154/1011263ar/

Dam V. H. \& Zethsen, K. K. (2016). The translation profession: centres and peripheries. The Journal of Specialised Translation, 25, 2-13. Retrieved from, https://www.jostrans.org/issue25/art_intro.pdf

Ersoy, H. and Erkurt, G. Ş. (2014). Kültür planlayıcısı olarak çevirmenin ve çevirinin erek kültür/toplumda sosyal değişimlere etkisi ve bu bağlamda geliştirilmesi gereken devlet politikaları. Uluslararası Sosyal Araştırmalar Dergisi, 7(33), 120-134. Retrieved from, http://www.sosyalarastirmalar.com/cilt7/sayi33_pdf/1dil_edebiyat/ersoy_huseyin_vd.pdf

Eruz, S. (2012). Çeviri derneği ve Türkiye'de çevirmenlik mesleğinin statüye kavuş(a)maması üzerine on üç yıllık gelgitli bir öykü. Avrupa Birliği Bakanlı̆̆ Çeviri Platformu Bildirileri. İstanbul. 1723. Consulted on October 11, 2019. Retrieved from https://www.ab.gov.tr/files/ceb/Ceviri_Platformu_Resimleri/platform_bildirileri.pdf

Eser, O. (2013). Çeviri eğitiminde edinç kavramını değerlendirilmesi (Phd thesis). University of İstanbul, İstanbul, Turkey.

Esteves, L. M.R. (2005). Intellectual Property and Copyright: The Case of Translators. Translation Journal, 9(3). Retrieved from, http://accurapid.com/journal/33copyright.htm

Gilıç, R. Z. (2020). Çeviri eğitimine yönelik yeti temelli çeviri süreci ilişkisi. RumeliDE Dil ve Edebiyat Araştırmaları Dergisi, 21, 915-932. DOI: 10.29000/rumelide.843015.

Godbout, M. (2012). Looking to the sociology to trace a more successful path towards the professionalization of translation. Paper presented in the Eight Symposium on Translation, Interpretation and Terminology. Havana, Cuba. (11-13 December 2012).

Godbout, M. (2016). Lack of status- are translators the authors of their own misfortune? Circuit 131. Consulted on July 24, 2019. Retrieved fromhttps://www.circuitmagazine.org/dossier-131/lackof-status-are-translators-the-authors-of-their-own-misfortune>.

Gouadec, D. (2007). Translation as a Profession. Amsterdam/Philadelphia: John Benjamins.

Gouanvic, J. M. (2005). A Bourdieusian theory of translation, or the coincidence of practical instances: Field,'habitus', capital and 'illusio'. The translator, 11(2), 147-166.

Hanisch, A.. (2017). Official sworn translators in Turkey [blog post], October 17, 2017. Consulted on July 27, 2019. Retrieved from, https://yellali.com/blogs/article/558/official-sworn-translatorsin-turkey

Hlavac, J. (2013). A cross-national overview of translator and interpreter certification procedures. Translation and Interpreting 5(1), 32-65. Retrieved from, http://www.transint.org/index.php/transint/article/view/184

Inghilleri, M. (2005). The sociology of Bourdieu and the construction of the 'object'in translation and interpreting studies. The translator, 11(2), 125-145

\begin{tabular}{|c|c|}
\hline & \\
\hline eliDE Dil ve Edebiyat Araşttrmaları De & E Journal of Language and Literature Studies \\
\hline 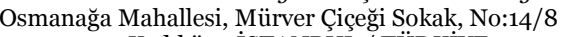 & Mahallesi, Mürver Çiçeği Sokak, No:14/8 \\
\hline Kadıköy $-\mathrm{I}$ & ISTANBUL / TURKEY 34714 \\
\hline $\begin{array}{r}\text { e-posta: editor } \\
\text { tel: }+905057958124,+9\end{array}$ & $\begin{array}{l}\text { editor@rumelide.com, } \\
\text { +90 505 7958124, +90 } 2167730616\end{array}$ \\
\hline
\end{tabular}


An in-depth analysis of the status quo of translation profession in Turkey from the perspective of trait theory of professionalization / N. M. Uysal (pp. 841-860)

Kafi, M., Khoshsaligheh, M.\&Hashemi, M.R. (2018). Translation profession in Iran: Current challenges and future prospects. The Translator, 24(1), 89-103. Retrieved from, https://www.tandfonline.com/doi/full/10.1080/13556509.2017.1297693

Kang, M.S. \& Shunmugam, K. (2014). The translation profession in Malaysia: The translator's status and self-perception. Journal of Language Studies, 14(3), 191-2015. Retrieved from, http://ejournals.ukm.my/gema/article/view/5829/2956

Kang, M.S.. (2015). A Comparative Study of the Translation Profession in Malaysia and Korea. (PhD dissertation), University of Malaya, Kuala Lumpur, Malaysia.

Katan, D. (2009). Translation theory and professional practice: A global survey of the great divide. Hermes 42, 111-154. Retrieved from, https://tidsskrift.dk/her/article/view/96849

Katan, D. (2011). Occupation or profession: A survey of the translators' world. Translation and Interpreting Studies 4(2), 187-209 https://doi.org/10.1075/tis.4.2.04kat

Kobya, S. and Karabacak, F. (Eds). (2015). Çeviri kitabr. İstanbul: Universal. Consulted on June 25, 2019. Retrieved from, https://www.cevirikitabi.com/cevirmenler-ne-isler ceviriyor/turk-cevirisektoru-kimlik-karti/

Köktürk,Ş.\&Türkmen, G. (2020) . Çevirmen edinci ve bileşenleri önerisi. International Journal of Languages Education and Teaching, 8(1), 188-197. DOI : 10.29228/ijlet.39606

Massardo, I. and Van Der Meer, J. (2017). The translation industry in 2022. The Netherlands: TAUS BV, De Rijp. Consulted on August 15, 2019. Retrieved from, https://cdn2.hubspot.net/hubfs/2734675/Reports,\%20ebooks/The\%2oTranslation\%2oIndustr y\%20in\%202022.pdf

Nimdzi 100. (2018). The size and the state of the language services industry, including ranking of top 100 LSPs by revenue. Consulted on August 15, 2019. Retrieved from, https://www.nimdzi.com/wp-content/uploads/2018/o3/2018-Nimdzi-100-First-Edition.pdf

Öner-Bulut, S. (2019). Integrating machine translation into translator training: towards 'human translator competence'?. TransLogos 2(2), 1-26. doi: http://dx.doi.org/10.29228/transLogos.11

Öner, S. (2012). Çevirmenlik “mesleği”-çeviri eğitimi ilişkisi bağlamında Türkiye'de çeviri alanına bakış. İstanbul. 17-23. Consulted on October 11, 2019. Retrieved from https://www.ab.gov.tr/files/ceb/Ceviri_Platformu_Resimleri/platform_bildirileri.pdf

Ören, T. (2020).Türkiye'de Çeviribilim Bölümlerinde Teknoloji Edincini Kazandırmaya Yönelik Derslerin İncelenmesiİstanbul Üniversitesi Çeviribilim Dergisi - Istanbul University Journal of Translation Studies 12, 77-108 DOI: 10.26650/iujts.2020.12.0005

Paloposki, O. (2016). Translating and translators before the professional project. The Journal of Specialized Translation, 25. Retrieved from, https://www.jostrans.org/issue25/art_paloposki.php

Pym, A., Grin, F., Sfreddo, C. \& Chan, A.L.J. (2012). The status of the translation profession in the European Union, studies on translation and multilingualism, Final Report. Brussels: The European Commission's Directorate- General for Translation. Consulted on September 25, 2019. Retrieved from, https://www.ocpe.nl/wp-content/uploads/2013/o2/The-Status-of-thetranslation-profession-in-the-EU.pdf

Pym, A., Orrego-Carmona, D. \& Torres- Simon, E. (2016). Status and technology in the professionalization of translators. Market disorder and the return of hierarchy. The Journal of Specialized Translation 25. Retrieved from, https://www.jostrans.org/issue25/art_pym.php

Romaine, M. \& Richardson, J. (2009). State of the translation industry 2009, smarter, more casual. My Gengo. Consulted on July 18, 2019. Retrieved from, https://workfortranslators.files.wordpress.com/2009/10/mygengo_state_of_translationindust ry_2009.pdf

\footnotetext{
RumeliDE Dil ve Edebiyat Araștırmaları Dergisi Osmanağa Mahallesi, Mürver Ciçeği Sokak, No:14/8 Kadıköy - İSTANBUL / TÜRKIYE 34714 e-posta: editor@rumelide.com 
Ruokonen, M. (2013). Studying translator status: Three points of view. HaasteenaNakökulma, Perspektivet Som Utmanig, Point of View as Challenge, Perspektivitat als Hearusforderung. VAKKI-Symposium XXXIII 7-8 February 2013. Vaasa: VAKKI, 327-338.

Ruokonen, M. (2016). Realistic but not pessimistic: Finnish translation students' perspectives of translator status. Journal of Specialized Translation, 25, 33-53. Retrieved from https://www.jostrans.org/issue25/art_ruokonen.pdf

Seguinot, C. (2007). Translation and the changing profession: a cross-disciplinary perspective. Translation, Terminologie, Redaction. 20(1), 171-191. Retrieved from, https://www.erudit.org/en/journals/ttr/2007-v20-n1-ttr2280/018502ar/

Sela-Sheffy, R. (2016). Professional identity and status. In Angelelli, Claudia V. \& Baer, Brian James (Eds.), Researching Translation and Interpreting (131-145). Milton Park and New York: Routledge.

Setton, R., \& Liangliang, A.G. (2011). Attitudes to role, status and professional identity in interpreters and translators with Chinese in Shanghai and Taipei. In R. Sela-Sheffy\&M. Shlesinger (Eds.) Identity and Status in the Translational Professions (89-117). Amsterdam: John Benjamins.

Stejkal, J. (2004). Certification of Translators and Interpreters: Seminar on Standards and Certifications in the T\&I Industry. Consulted on August 02, 2019. Retrieved from, http://www.jtpunion.org/getattachment/O-profesi-Akce/Odborne/Neco-ke cteni/Credentialing-of-Translators-and-Interpreters-An-I/IMG-ppt certif.ppt.aspx

Stejkal, J. (2005) Survey of the FIT committee for information on the status of the translation \& interpretation profession. Consulted on August 02, 2020. Retrieved from, http://www.uta.org.ua/data/loads/fit_survey_report-2005-07.pdf.

Svahn, E., Ruokonen, M. \& Salmi, L. (2018). Boundaries around, boundaries within: Introduction to the thematic section on the translation profession, translator status and identity. Hermes Journal of Language and Communication in Business, 58, 7-17. Retrieved from, https://www.jiaotongbakercentre.org/2019/01/02/new-publication-hermes-journal-oflanguage-and-communication-in-business-no-58/

Tahir-Gürçağlar, Ş. (2011). Çevirinin ABC'si. İstanbul: Say.

Tekgül, D. (2008). Türkiye’de Çeviri Eğitimi Veren Üniversite Bölümleri In Çeviri Seçkisi I: Çeviriyi Düşünenler (60-63). İstanbul: Sel.

The Prime Ministry Directorate For Administration Development [PMDGAD]. (2015). The translation profession in Turkey, Research Consulted on July 12, 2019. Retrieved from, http://www.ankaced.org/images/cevirmenlikraporu.pdf

The Prime Ministry Directorate For Administration Development [PMDGAD]. (2011). The translation profession in Turkey, Research Report.Consulted on July 12, 2019. Retrieved from, http://www.konsolostercume.com/Turkiyede\%20Cevirmenlik\%20Meslegi\%20\%20Arastirma\%20Raporu.pdf

Turkey Legal Gazette. (2004). Criminal Code. Consulted on June 21, 2019. Retrieved from, http://www.shb.gen.tr/uploads/mevzuat/CRIMINAL_CODE.pdf

Türkmen, B. (2019). Çeviri eğitiminde teknoloji ve dijital medya. Ankara: Gece Kitaplığı.

Uysal, N.M., Odacıoğlu, C. and Köktürk, Ş. (2015). Meslekleşme açısından Türkiye'de çevirmenliğin mevcut durumu, sorunlar ve çözüm önerileri Uluslararası Sosyal Araşttrmalar Dergisi, 8(36), 257-266. Retrieved from,

http://www.sosyalarastirmalar.com/cilt8/sayi36_pdf/1dil_edebiyat/uysal_muge_cemodaciogl u.pdf

Uysal, N.M. (2017a). Çevirmenlikte meslekleşme ve çevirmen sertifikasyonu. Ankara: Gece Kitaplı̆̆

Uysal, N.M. (2017b): Türkiye'de Çevirmenlik Mesleği ve Çevirmen Sertifikasyon Sistemi (Doctoral Thesis). Sakarya: University of Sakarya.

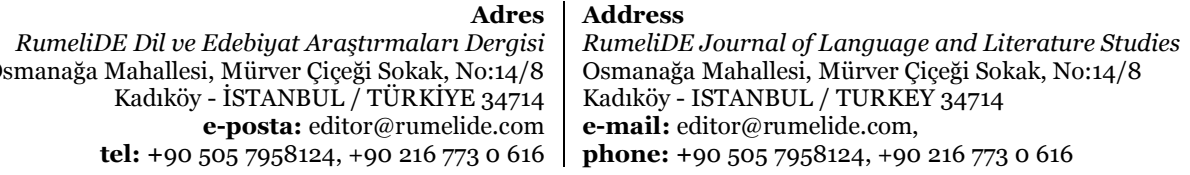

RumeliDE Dil ve Edebiyat Araşttrmaları Dergisi e-posta: editor@rumelide.com tel: +90 $5057958124,+902167730616$
Address

Osmana ̌a

e-mail: editor@rumelide.com

phone: +90 $5057958124,+902167730616$ 
Uysal, N.M. (2020). Çevirilerin resmi olarak onaylanması: Ülkemizde yeminli tercümanlık müessesesi ve dünyadaki yeminli/tasdikli çeviri uygulamaları üzerine genel bir değerlendirme. RumeliDE Dil ve Edebiyat Araştırmaları Dergisi, 18, 709-724. Retrieved from, https://doi.org/10.2900o/rumelide.706503

Venuti, L. (1986). The translator's invisibility. Criticism, 28(2), 179-212.

Vigier, F. J. \& Way, C. (2009). Comparing European Qualifications in the Realm of Official Translating and Interpreting. In Ian Kemble (Ed.) The Changing Face of Translation: Proceedings of the Eighth Annual Portsmouth Translation Conference (143-153). University of Portsmouth. Retrieved from, http://www2.port.ac.uk/media/contacts-and-departments/slas/events/tro8vigier.pdf

Vocational Qualifications Institution [VQI]. (n.d). Türkiye Yeterlilikler Çerçevesi Tanıtım Broşürü. Consulted on September 12, 2019. Retrieved from, https://www.myk.gov.tr/images/articles/TYC/tyc_brosur.pdf)>

Vocational Qualifications Institution [VQI]. (2015a). Vocational Qualifications System. Consulted on September 12, 2019, <https://myk.gov.tr/TRR/File6.pdf >

Vocational Qualifications Institution [VQI]. (2015b). Ulusal Meslek Standardı, Çevirmen Seviye 6. Consulted on October 11, 2019. Retrieved from, file://C:/Users/pc/Downloads/12UMSo2746\%2oRev\%2000\%20\%C3\%87evirmen\%20(1).pdf

Vocational Qualifications Institution [VQI]. (2018). Ulusal Yeterlilik, Özel Alan Çevirmeni, Seviye 6 Consulted on June 25, 2019. Retrieved from, <https://www.myk.gov.tr/index.php/en/haberler/34-meslek-standartlar-dairesi-bakanl/3466cevirmenlik-alanna-ait-6-adet-taslak-yeterlilik-goeruee-ckt>.

Wolf, M. \& Fukari, A. (Eds.). (2007). Constructing a Sociology of Translation. Amsterdam: John's Publishing Co.

Yllmaz-Gümüs, V. (2018). Solidity and professionalization of translation: Turkey as a case in point. Hermes-Journal of Language and Communication in Business, 58, 44-60. Retrieved from https://tidsskrift.dk/her/article/view/111661

\footnotetext{
Adres

RumeliDE Dil ve Edebiyat Araşttrmalar Dergisi Osmanağa Mahallesi, Mürver Çiçeği Sokak, No:14/8 Kadıköy - ISTANBUL / TÜRKIYE 34714 e-posta: editor@rumelide.com tel: +90 $5057958124,+902167730616$

Address

RumeliDE Journal of Language and Literature Studies

Osmanağa Mahallesi, Mürver Çiçeği Sokak, No:14/8

Kadıköy - ISTANBUL / TURKEY 34714

e-mail: editor@rumelide.com,

phone: +90 505 7958124, +90 2167730616
} 